\title{
RAPID MEASUREMENT OF BLOOD PROPOFOL \\ LEVELS: A PROOF OF CONCEPT STUDY
}

L. McGaughran, BAppSc, ${ }^{1}$ L.J. Voss, PhD, ${ }^{2}$ R. Oliver, $M S c,{ }^{3}$ M. Petcu, BSc (hons), ${ }^{3}$ P. Schaare, PhD, ${ }^{3}$ J.P.M.

Barnard, MBChB, FANZCA, ${ }^{2}$ and J.W. Sleigh, MD,

$M B C h B, F A N Z C A^{2}$

Journal of Clinical Monitoring and Computing (2006) 20: 109-115 DOI:10.1007/s10877-006-9014-3

Due to a processing error, the fourth author's name was missing in the HTML version of this article.

${ }^{1}$ From the Auckland University of Technology, Auckland, New Zealand, ${ }^{2}$ Department of Anaesthesiology, Auckland University, New Zealand, ${ }^{3}$ Biosensors and Biomeasurement, HortResearch, Hamilton, New Zealand. 